\title{
CARTA DO EDITOR DAS EDIÇÕES ESPECIAIS DE ENCONTROS BIBLI
}

\section{A ARTE DE TECER REDES E A CIÊNCIA DA INFORMAÇÃO}

Há muitas décadas, a noção de redes humanas vem se consolidando como tema de interesse capaz de produzir explicações sobre o âmbito de interação entre as pessoas que compõem as sociedades, vindo daí a concepção de redes sociais. Essa noção conduz um conteúdo que lhe confere a idéia de um "espaço" para a promoção de encontros entre os indivíduos. Essa interação sustenta-se na consciência individual, que se torna aparência - portanto, se estende a outros indivíduos - de que há uma realidade construtora dessas individualidades e, simultaneamente, de que é uma realidade por elas construída.

Nesse sentido, a interação de que falamos é produto e processo de subjetivação e assimilação, de um lado, e de exteriorização e objetivação, de outro. Pela subjetivação, tentamos interiorizar as mensagens que nos atingem, comparamo-las com o que já conhecemos, damos-lhes um lugar em nosso universo conceitual e de práticas e agregamo-las ao corpo de saber que dominamos. Esse conhecimento, provavelmente, transformará todo ou parte do acervo de saber que já possuímos, dando elementos para a reformulação de valores, noções e idéias que expressamos, ou melhor, objetivamos. Essa objetivação como uma exteriorização do nosso saber, se manifesta sob a forma de textos explanatórios, mensagens da linguagem corporal, seleções de arte, soluções que produzimos no andamento de nossas atividades, idéias que defendemos, etc. E tudo isso requer que estejamos inseridos em espaços de domínio de outros e com outros.

Estamos em espaços de outros, quando chegamos a um lugar e nele interferimos já pelo simples fato de lá ter chegado, pela leitura que pode ser feita da nossa presença, de nosso exterior: por nossa vestimenta, pelos nossos modos de andar, olhar, gesticular e que se amplia quando começamos a usar a linguagem oral. Interferimos pelo conteúdo de uma mensagem quando falamos e somos compreendidos pela linguagem que usamos, mas também interferimos quando falamos em uma língua estranha ao ambiente e, com isso, obrigamos, aos circunstantes, a mobilizar uma série de estratégias na

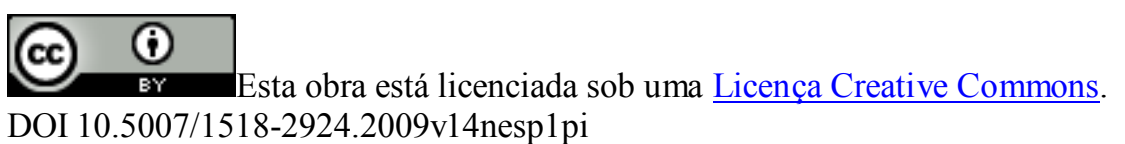


tentativa de que tal interferência não seja apenas de forma.

É a isso que atribuímos a noção da existência de rede humana, isto é, a uma mobilização de outros em torno de um fenômeno, utilizando os meios disponíveis e apropriáveis.

Norbert Elias, em seu livro A Sociedade dos Indivíduos (Organizado por Michael Schrötter. Edição Brasileira de Jorge Zahar Editor, Rio de Janeiro, 1994, com tradução de Vera Ribeiro), nos oferece uma argumentação do que poderia ser tomado como a formação de rede humana e sua dinâmica:

\begin{abstract}
"...a rede [está] em constante movimento, como um tecer e destecer ininterrupto das ligações. É assim que efetivamente cresce o indivíduo, partindo de uma rede de pessoas que existiam antes dele para uma rede que ele ajuda a formar. A pessoa individual não é um começo e suas relações com as outras não têm origem primeva. Assim como, numa conversa contínua, as perguntas de um evocam as respostas do outro e vice-versa, e assim como determinada parte da conversa não provém apenas de um ou do outro, mas da relação entre os dois, a partir da qual deve ser entendida, também cada gesto e cada ato do bebê não são produtos do seu "interior" nem de seu "ambiente", nem tampouco de uma interação entre um "dentro" e um "fora" originalmente distintos, mas constituem uma função e um precipitado de relações, só podendo ser entendidos - como a imagem do fio numa trama - a partir da totalidade da rede". p 35
\end{abstract}

Esta edição especial temática de Encontros Bibli reúne muitos dos fenômenos que constituem elementos necessários a essa noção de rede ou trama. Primeiro, a interlocução entre pesquisadores brasileiros e canadenses; segundo, a interação de interesses temáticos, no âmbito da Ciência da Informação, a envolver Leitor, Leitura, Livro, Memória, Arquivos, Bibliotecas, Arquivistas, Bibliotecários, práticas profissionais, legitimação teórica de práticas profissionais, etc.; terceiro, a interlocução de pesquisadores no ambiente acadêmico brasileiro, reunindo a exposição de membros de diferentes instituições de diversas regiões do país. Enfim, poderíamos listar outras facetas a demonstrar a arte de tecer redes que tornou possível a composição deste fascículo.

Uma das formas de representar rede é evidenciar seus nós. São os nós, ou o "lugar" de encontro dos vários fios, isto é, das objetivações produzidas no caso de idéias e pensamentos humanos, que permitem a aceleração da difusão e acumulação do conhecimento. Assim, arquivos e bibliotecas, profissões e profissionais, linguagens e códigos de conduta profissional, etc., dão-se como esses nós. Também esta edição de 
Encontros Bibli é um desses nós da rede. São as idéias aqui apresentadas, mas também os seus autores e autoras que evidenciam uma rede, ainda que em si sejam membros de outras tantas e incontáveis redes.

Dito isto, uma vez mais, desejamos a todo o público de Encontros Bibli a mais calorosa leitura e a possibilidade de inserir-se nas discussões trazidas nesta edição, a qual expõe dimensões significativas da Ciência da Informação, Arquivologia, Memória e Biblioteconomia.

Para concluir, agradeço o empenho das organizadoras da edição em mobilizar autores e Comissão Editorial ad hoc e também ao pessoal de suporte de Encontros Bibli pela dedicação à concepção, produção e publicação deste número.

Prof. Francisco das Chagas de Souza, Dr.

Editor das Edições Especiais de Encontros Bibli

Departamento de Ciência da Informação

Programa de Pós-Graduação em Ciência da Informação

Universidade Federal de Santa Catarina

Brasil

chagas@,cin.ufsc.br

http://nipeeb.blogspot.com/

Florianópolis, Ilha de Santa Catarina, junho de 2009. 